\title{
O LUGAR DO PROFESSOR NAS IMAGENS DA NOVA ESCOLA
}

\author{
The teacher's place in images from Nova Escola magazine
}

\begin{abstract}
Daniel Revah
Docente do curso de Pedagogia da Universidade Federal de São Paulo (Campus Guarulhos), Doutor em Educação pela Faculdade de Educação da Universidade de São Paulo, São Paulo, SP - Brasil, e-mail: daniel.revah@unifesp.br
\end{abstract}

\begin{abstract}
Resumo
No Brasil, na década de 1980, a emergência do discurso pedagógico construtivista (re)ordenou os discursos educacionais precedentes, incidindo desse modo no lugar do professor, ou melhor, da professora, que é o que corresponde ao gênero predominante no nível pré-escolar e no então chamado $1^{\circ} \mathrm{Grau} \%$ os níveis de ensino onde esse discurso se constitui e instala com maior ressonância. Este trabalho analisa imagens de capa da revista Nova Escola, publicada desde 1986, numa média de dez números anuais. Essas imagens permitem evidenciar aspectos relativos a esse (re)ordenamento e à (re)configuração do lugar do professor sob a égide do construtivismo, no período que se estende do momento imediatamente anterior a essa emergência até meados da década de 1990, quando no construtivismo ocorre uma importante inflexão. Para tratar dessa emergência e do (re)ordenamento discursivo correspondente foi desenvolvido o conceito de significante de ressonância, que é um pequeno desdobramento do conceito de significante-mestre formulado por Lacan. Neste artigo, significantes como "Emilia Ferreiro", "Piaget" e "Construtivismo" são concebidos primeiramente como significantes-mestres que adquiriram ressonância social, ao serem esgrimidos em inúmeras falas, nas décadas de 1980 e 1990, para defender, situar, reconhecer ou atacar determinadas posições no campo da educação escolar. Por meio desses significantes de ressonância e de outros a eles vinculados, processa-se o (re)ordenamento discursivo que resultou na emergência do construtivismo e em mudanças significativas no lugar do professor.
\end{abstract}

Palavras-chave: História da educação. Discurso educacional. Construtivismo.

\begin{abstract}
The emergence of the constructivist pedagogical discourse in Brazil, during the 1980's, (re)ordered the former pedadogical discourses, thus affecting the place of the teachers, predominantly female, in kindergarten and what was then called "primeiro grau" ( $1^{\text {st }}$ through $4^{\text {th }}$ grades), the school
\end{abstract}


levels at which this discourse achieved greatest resonance. This work analyzes images taken from covers of the Nova Escola magazine, which has been published in ten issues per year on average since 1986. These images show aspects of this discursive (re)ordering and the (re)configuration of the teachers' place under Constructivism from the moment immediately preceding its emergence to the mid-1990's, when Constructivism came to an important turning point. In order to understand the emergence of Constructivism and the discursive (re)ordering that followed it we have developed the concept of resounding signifiers, which derives from Lacan's concept of master signifier. In this paper signifiers such as "Emilia Ferreiro", "Piaget" and "Constructivism" are firstly conceived as master signifiers which acquired social resonance by being brandished in speeches during the 1980's and 1990's in order to defend, situate, recognize or attack certain positions in the field of school education. By means of these resounding signifiers and related ones the discursive (re)ordering took shape that resulted in the emergence of Constructivism and in meaningful changes in the teacher's place.

Keywords: History of education. Educational discourse. Constructivism.

\section{INTRODUÇÃO}

No Brasil, na década de 1980, a emergência do discurso pedagógico construtivista (re)ordenou os discursos educacionais precedentes, incidindo desse modo no lugar do professor, ou melhor, da professora, que é o que corresponde ao gênero predominante no nível pré-escolar e no então chamado $1^{\circ}$ Grau \% os níveis de ensino nos quais esse discurso se constitui e se instala com maior ressonância. Este trabalho analisa imagens de capa da revista Nova Escola que permitem evidenciar aspectos relativos a esse (re)ordenamento e à (re)configuração do lugar do professor sob a égide do construtivismo, no período que se estende do momento imediatamente anterior a essa emergência até meados da década de 1990, quando no construtivismo ocorre uma importante inflexão. ${ }^{1}$

A revista Nova Escola é publicada ininterruptamente desde 1986 até hoje, numa média de dez números anuais. O seu público alvo são os professores do $1^{\circ} \mathrm{Grau}$ (atual Ensino Fundamental), como é possível notar na capa da revista já no primeiro número, pois o nome vem acompanhado deste enunciado complementar: "Para professores do $1^{\circ} \mathrm{Grau}$ " \% um enunciado que se mantém até 1995. De alcance nacional e com a intenção de cobrir todas as regiões do Brasil, desde o início e por vários anos a Nova Escola foi distribuída em "cada uma das 220.000 escolas públicas de $1^{\circ}$ Grau existentes no país", graças a um contrato firmado entre a Fundação Victor Civita, responsável pela edição da revista, e o Ministério da Educação. ${ }^{2}$ A revista obteve boa repercussão entre os professores, não sendo poucos os que nela se espelhavam, utilizando-a ademais como fonte para recriar as suas práticas. A forma jornalística e os dispositivos de leitura característicos de outras revistas comerciais fazem parte da estratégia editorial desse periódico educacional, vinculado por meio daquela fundação à editora Abril. Um periódico que, segundo o editorial do primeiro número, "não é nem deseja ser uma publicação pedagógica", mesmo tendo como um de seus objetivos "fornecer à professora informações necessárias a um melhor desempenho do seu trabalho" (Civita, 1986, p. 5). Produzida por "uma equipe de experimentados jornalistas", além de "profissionais da Educação" (Civita, 1986, p. 5), em muitas reportagens é comum encontrar falas de professores, alunos, pais de alunos, políticos, ocupantes de cargos em secretarias e especialistas vinculados às universidades, em textos que costumam contextualizar as práticas e experiências educacionais objeto dessas matérias. É o que pelo menos predomina na década de 1980 e parte da seguinte, antes da transformação que se observa ainda na primeira metade da década de 1990, com a mudança do diretor de redação (sai Ana Maria

\footnotetext{
1 Este trabalho é uma versão ampliada de comunicação feita no VII Congresso Luso-Brasileiro de História da Educação, em junho de 2008.

2 “Carta do editor" assinada por Victor Civita, Nova Escola, (1), 5, mar. 1986.
} 
Sanchez e assume Vitor Strauss), em outubro de 1984 , e a nova política editorial, que altera sobremaneira os dispositivos de leitura. ${ }^{3}$

A Nova Escola, como seu próprio nome sugere, desde o início mostra-se uma publicação sensível à mudança e ao novo, que são algumas das marcas que definem o semblante com que o construtivismo emerge. Desse modo, mas também em virtude das características acima assinaladas, a revista delimitou um terreno propício para a análise da emergência desse discurso pedagógico e das transformações que ocorreram no lugar do professor, que é o que está em foco neste trabalho. Quando é iniciada a sua publicação, o significante-mestre construtivismo ainda não tinha adquirido maior ressonância \% nesse periódico começa a ser utilizado em 1989.

Neste estudo, o discurso pedagógico construtivista é concebido como uma rede simbólica constituída por um conjunto de pontos de ressonância \% um conceito que é um pequeno desdobramento do conceito de ponto de basta de Lacan (1997). Esses pontos de ressonância surgem graças ao uso reiterado de determinados significantes em determinado campo, neste caso o campo da educação escolar. Significantes-mestres, na conceitualização de Lacan, e aqui chamados de significantes de ressonância em alusão ao fato de serem usados nas falas de inúmeros sujeitos, assim adquirindo ressonância social. São significantesmestres, portanto, diferentes dos que têm um caráter estritamente singular e que concernem ao desejo e história de determinado sujeito. Com eles são criados os nós ou pontos de ressonância que definem determinado discurso social e que em si condensam inúmeras articulações discursivas que surgem nos atos de fala. Essas articulações discursivas são as que definem os sentidos e as significações produzidas pelos significantes de ressonância a que se vinculam. Estes, sempre unidos numa rede da qual fazem parte, encontram-se vinculados de diversos modos, mantendo inclusive laços com outros discursos, até mesmo de outros campos. Fracasso escolar, democracia, analfabetismo, escola tradicional, educação popular são exemplos de significantes de ressonância.
Entre esses significantes de ressonância é possível fazer uma distinção, pois existem aqueles cuja função no discurso é produzir uma espécie de fecho, um ponto de arremate no qual confluem inúmeras articulações discursivas que estão como que à procura de um sentido último, mesmo que nesse ponto nunca o encontrem. Esses significantes de arremate, usados frequentemente como forma de reconhecimento, em si condensam a rede toda, a rede relativa a determinado discurso e que sempre é virtual. Esse é o caso dos significantes de arremate Emilia Ferreiro, Piaget e construtivismo, que são equivalentes, pois cumprem a mesma função no discurso, pelo menos a partir do momento em que se constitui efetivamente um discurso pedagógico construtivista. ${ }^{4}$

Se tomarmos como referência a revista Nova Escola, a emergência do construtivismo pode ser situada na segunda metade da década de 1980. De início, esse novo discurso pedagógico configurase em estreito vínculo com o nome Emilia Ferreiro, que é o significante-mestre então esgrimido em inúmeras falas para reconhecer as propostas e práticas de alfabetização que surgem no encalço da pesquisa de Ferreiro e Teberosky (1986) sobre a psicogênese da língua escrita. Na revista Nova Escola, cujo primeiro número é de março de 1986, o nome Emilia Ferreiro é mencionado a partir de 1987, pelo menos segundo levantamento feito em várias matérias cujos temas sugeriam o seu possível uso. ${ }^{5} \mathrm{Na}$ capa da Nova Escola, o nome aparece na edição de março de 1989. A emergência do significante-mestre construtivismo é posterior, surge em algumas matérias a partir de 1989 e, como manchete de capa, em maio de 1991. Com ele, o discurso que inicialmente ficava restrito ao campo da alfabetização alarga as suas fronteiras em direção a outras áreas do ensino, configurandose assim um discurso de caráter mais amplo.

Esses significantes de ressonância, o seu movimento e as balizas que eles estabelecem, constituem neste trabalho uma referência fundamental para pensar tudo o que diz respeito a esse novo discurso pedagógico. Outra referência são os marcos e contornos, criados pela revista Nova Escola, que definemolugardo professor. A esse respeito, quatro momentos podem ser distinguidos. ${ }^{6} \mathrm{O}$ primeiro, relativo ao início dessa

\footnotetext{
3 Em relação às mudanças que ocorreram na revista, veja-se Revah (2004 e 2007a).

4 Sobre esses conceitos, veja-se Revah (2004).

5 Em relação à pesquisa realizada na revista Nova Escola, veja-se Revah (2004).

6 A separação em momentos não deve ser tomada de uma forma estanque, pois concerne a tendências predominantes em determinadas períodos, o que não significa que desapareçam quando deixam de predominar.
} 
publicação, corresponde ao lugar de professores criativos e corajosos, discretos e eficazes, realistas e aplicados que estão empenhados em mudar o $1^{\circ}$ Grau. Em poucos anos, porém, em sintonia com a emergência do construtivismo, configura-se o que é da ordem de uma falta no lugar do professor: falta o bom professor, a boa professora. Esta deverá emergir na primeira metade da década de 1990, num terceiro momento, com a imagem da professora construtivista. A suposta boa professora, a professora construtivista, sofrerá no entanto as injunções da deriva desse mesmo discurso, em meados dessa mesma década, quando o construtivismo adquire um claroviés tecnicista a professora parecedesaparecer.

\section{Os professores da "reforma silenciosa"}

Vejamos então como é configurado o lugar do professor no início dessa publicação, em abril de 1986, na primeira edição cuja manchete e imagem de capa aludem aos professores, ao destacar o seu papel neste enunciado que complementa a manchete: "Como nossos professores estão mudandoo $1^{\circ}$ Grau".

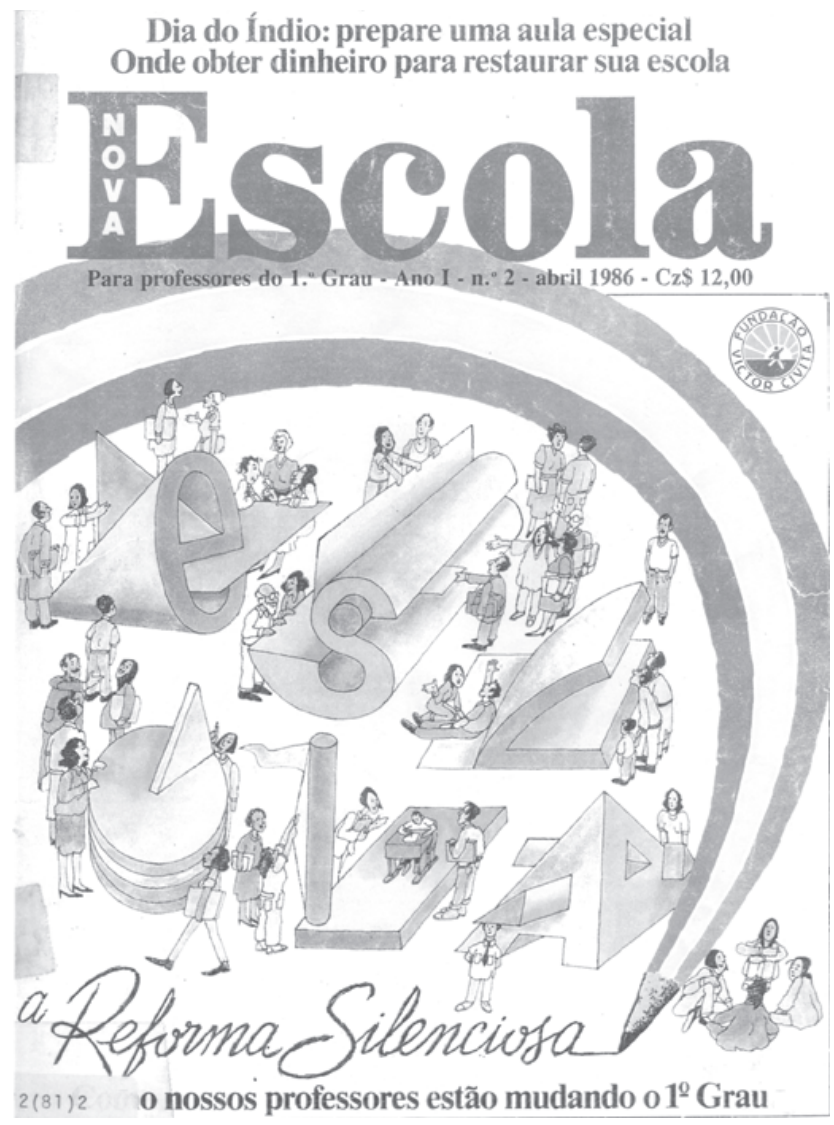

FIGURA 1 - Nova Escola, ano I, n. 2, abr. 1986 Fonte: Editora Abril
$\mathrm{Na}$ imagem de capa dessa edição (Figura 1) predominam as cores da bandeira brasileira, notadamente no fundo amarelo e no lápis, que à maneira de um arco-íris está como que abraçando e assim contendo as letras da palavra "escola", e as pequenas figuras humanas que completam a imagem, na sua maioria sugerindo professores. Além deles, há uma criança-aluno em sua carteira, segurando um lápis, como se estivesse escrevendo, com uma professora inclinada em sua direção, ao que parece falando ou ditando-lhe um texto, poder-se-ia supor. E um professor que observa a cena, própria de uma sala de aula. Há também uma outra criança, junto com um casal, que o leitor poderia imaginar serem os seus pais. O pai está segurando a mão do filho, enquanto o casal mantêm uma atitude semelhante à de quem está lendo ou olhando com atenção algo fixado, talvez, numa parede ou mural da escola. São mais de trinta professores em situações diversas, numa imagem que sugere movimento: alguns circulam com seus materiais (pastas, maletas, folhas) e muitos estão conversando, em duplas ou trios. Do lápis, procede a escrita da manchete "A reforma silenciosa" \% reforma feita pelos professores que estão "mudando o $1^{\circ}$ Grau".

O lápis cujo movimento produz aquela escrita parece condensar os vários elementos presentes na capa dessa edição: professores, escola, Reforma, Brasil \% elementos que podem ser tomados como uma série significante que conflui sobre o mesmo ponto. Os professores do Brasil empenhados em mudar a escola de $1^{\circ}$ Grau são, por assim dizer, o próprio lápis que escreve/produz a Reforma. O seu movimento corresponde à circulação dos professores na imagem de capa, entre as letras da palavra escola. Esse "movimento" dos professores, assim caracterizado na reportagem que corresponde ao destaque de capa, é o que afinal produz a Reforma.

O que a imagem de capa apresenta são situações que lembram o dia-a-dia do professor, na escola ou em torno dela. Muitos estão conversando, em encontros típicos do cotidiano. Desse modo, o que aí é sugerido, na imagem e nos próprios enunciados, é um movimento feito de ações imperceptíveis, silenciosas, quase todas fora da sala de aula. São essas ações as que geram esse movimento de mudança que envolve o Brasil e que adquire um sentido patriótico e promissor, evocado pelas cores que predominam na imagem sob o lápis/arco-íris. Temos aí implicada uma valorização do cotidiano como lugar onde se gesta 
o "movimento" que produz a "Reforma", vista como algo urgente em face do que os educadores brasileiros "classificam de a 'falência' da escola pública de $1^{\circ}$ Grau", de acordo com a reportagem que corresponde ao destaque de capa. ${ }^{7}$ Nela, afirmase que "um número incalculável" de educadores brasileiros "tomou a si a tarefa de mudar o desagradável panorama da Educação no Brasil, pelo menos no que se refere ao $1^{\circ}$ Grau" (ibidem). E continua: "Os efeitos desse movimento já se mostram amplos o suficiente para merecerem o batismo de 'reforma' [...] que na maioria das vezes surge de iniciativas individuais ou da decisão de pequenos grupos" (Nascimento, 1986, p. 10). Além disso, "o movimento não tem precisado de leis, decretos ou das clássicas 'ordens superiores' para legitimar-se” (Nascimento, 1986, p. 10).

A valorização do cotidiano como lugar de mudanças importantes inscreve as ações dos professores numa série cujo desdobramento, se seguirmos os discursos do período, leva-nos até os movimentos, ações e discursos que desde os anos de 1970, sob a ditadura militar, tornaram o cotidiano um espaço de pequenas lutas e de transformações que efetivamente tiveram forte impacto do ponto de vista político e cultural, envolvendo determinado setor das camadas médias e os setores populares que se organizaram em movimentos cuja confluência fortaleceu as lutas pela democracia. A Nova Escola surge justamente na chamada Nova República, com o primeiro presidente civil após 20 anos de ditadura militar. Situar os professores no cotidiano, na posição dos que estão mudando o Brasil, é de certo modo inscrevê-los nessa mudança mais ampla, relacionada com o fim da ditadura e com a emergência desses movimentos e grupos sociais que reelaboraram o seu cotidiano dando um sentido político às pequenas transformações do seu dia-adia. Um sentido que, por meio dessa valorização do cotidiano, foi alargado e transfigurado, segundo Sader (1988), se o compararmos com as formas de fazer política até então consagradas.

$\mathrm{Na}$ reportagem intitulada "Reforma Silenciosa", no texto introdutório destacado em negrito, os professores são assim caracterizados:

Discretos e eficazes, eles adaptam os currículos à realidade de seus alunos. Corajosos e criativos, desafiam as leis para suprir a falta da pré- escola. Realistas e aplicados, voltam a estudar para oferecer um trabalho mais eficiente... é assim que um número sempre crescente de professores tenta descobrir um novo caminho para a Educação de $1^{\circ}$ Grau.

Apesar do lugar que a reportagem constrói para os professores - na imagem e enunciados de capa e na introdução -, conforme se avança na leitura do texto configura-se um outro lugar, pois o que sobressai são as iniciativas de diretores de escolas públicas e secretarias de educação estaduais e municipais. Ou seja, a mudança resulta antes da iniciativa de dirigentes do ensino do que de ações desencadeadas pelos professores. Essas iniciativas são as mais diversas, ainda não há "um caminho", como mais tarde tende a se configurar com o construtivismo. Na matéria, destaca-se desde o aumento do tempo de alfabetização, o treinamento dos professores, as mudanças no currículo, a implantação do ciclo básico, o atendimento ao aluno quase individualizado, a avaliação diária, até a reforma e construção de prédios escolares e mudanças na sistemática da merenda.

O foco da matéria é a escola pública, que é o que deverá predominar na revista na década de 1980 e parte da seguinte, sem contar as matérias sobre outras formas de atendimento educacional voltadas para os setores populares. Em muitas matérias desses primeiros anos, nota-se também a relevância dada ao que extrapola a sala de aula, como tudo o que é situado por meio do significante "realidade" e que concerne ao contexto em que se desenrolam determinadas experiências, envolvendo as condições de vida e de trabalho do professor, as características da região ou bairro, as condições em que vivem as crianças-alunos e suas famílias. É o caso da reportagem da edição de junho de 1986, destacada na capa da revista com esta manchete: "Escola Rural. Uma lição de heroísmo". Na reportagem sobressaem as difíceis condições de vida de professores e crianças-alunos que estudam em escolas rurais. Sobre os últimos, aliás, o que predomina nas imagens de capa do primeiro ano da Nova Escola são "realidades" de crianças-alunos pertencentes a grupos e setores sociais de baixa renda, marginalizados, historicamente oprimidos ou que precisaram enfrentar e superar inúmeras dificuldades para ter acesso à escola. Essa

\footnotetext{
Nascimento, Nova Escola, (2), 10, abr. 1986.
} 
"realidade" não mais será a dos setores e grupos sociais que deverão ganhar espaço na revista Nova Escola na década de 1990, com o construtivismo na posição de discurso hegemônico.

\section{Falta o bom professor, a boa professora}

Ao falar da "falência" da escola pública, ao mencionar as altas taxas de reprovação já na $1^{a}$ série e o problema da evasão, a reportagem que alude à "reforma silenciosa" faz eco ao debate que vinha ganhando intensidade desde a década de 1970 sobre o chamado fracasso escolar - um tema cuja presença nos discursos brasileiros pode ser remontada ao final do Império. Na década de 1980, as causas do fracasso escolar cada vez mais tendem a ser situadas no âmbito do sistema de ensino, de modo que tendem a recuar as posições que o atribuíam a fatores externos à escola, como as condições socioeconômicas ou o suposto déficit cultural das crianças-alunos oriundas dos setores populares, como era próprio da tão criticada "teoria" da "carência cultural" ou "privação cultural" e cuja contrapartida era a chamada "educação compensatória" (Patto, 1985). No decorrer dos anos de 1980, esse deslocamento leva a focalizar a escola. E dessa maneira, nos discursos educacionais, o que é da ordem de uma falta, de uma falha, instala-se no interior da escola, com o principal imputado ficando sob a órbita do significante de ressonância escola tradicional, mesmo com a inversão que o discurso da chamada pedagogia dos conteúdos tende a operar no início dessa década, ao (re)ordenar o que esse significantemestre evocava e assim produzir a sua súbita valorização. ${ }^{8}$ No interior da escola, as causas, as responsabilidades, as razões do fracasso recaem sobre vários pontos, afunilando-se em certo momento na figura do professor, em particular com o construtivismo.

Esse deslocamento em direção à figura do professor pode ser apreendido percorrendo-se as matérias da década de 1980 da revista Nova Escola, mas também é indicado e reafirmado em textos de natureza teórica (Patto, 1985). Com o construtivismo, ademais, afirma-se todo um conjunto de articulações discursivas que criam e dão consistência a este ponto de ressonância: o dos "desvios, confusões, equívocos..." atribuídos aos professores, sobretudo na alfabetização, seja porque continuam com as suas concepções e práticas consideradas tradicionais, seja porque mal entendem as implicações teóricas e práticas das pesquisas e reflexões de Ferreiro e Teberosky sobre a psicogênese da língua escrita.

O tema dos "desvios, confusões, equívocos [...]," vinculado ao nome Emilia Ferreiro, começa a ser delineado na revista Nova Escola desde, pelo menos, 1988, como é possível notar na reportagem destacada na capa de junho desse ano, com esta manchete: "Pais x professores. A difícil convivência na hora da alfabetização." $\mathrm{Na}$ reportagem, já no primeiro parágrafo, afirma-se que "a prática vem comprovando que há muitos equívocos a respeito do papel de cada um na alfabetização, tanto do lado dos pais quanto do lado da escola, especificamente do professor" (Ferraz, 1988, p. 12). A matéria pretende, justamente, desfazer essas "confusões e equívocos", que, pela primeira vez, são mencionados numa matéria na qual se faz referência a Emilia Ferreiro, não sendo comum ou relevante esse tipo de constatação nos números anteriores da revista.

O que nesse período começa a circular nos discursos educacionais é o que aquele ponto de ressonância ajuda a instituir: a falta de um bom professor, de uma boa professora. Com o discurso pedagógico construtivista, o bom professor é aquele que compreendeu a teoria ou teorias construtivistas e sabe aplicá-las corretamente. Isso em grande parte supõe que o professor conhece a "criança que constrói seus próprios conhecimentos", adotando então uma postura em sala de aula que sempre considera essa construção. Definida nos termos da teoria psicogenética piagetiana, essa criança não é mais a criança-aluno que os discursos educacionais instituíam com o significante de ressonância "realidade da criança". Esta tende a ser sobrepujada e anulada pelos traços da criança suíço-piagetiana, como pode ser observado de modo nítido nas edições da Nova Escola de 1996 (Revah, 2007b).

Em 1988, falta o bom professor, a boa professora. Ao menos é o que poderíamos afirmar seguindo o que a revista Nova Escola configura no lugar do professor, em particular na capa da edição de novembro (Figura 2).

8 Sobre a pedagogia dos conteúdos, veja-se Saviani (1984). 


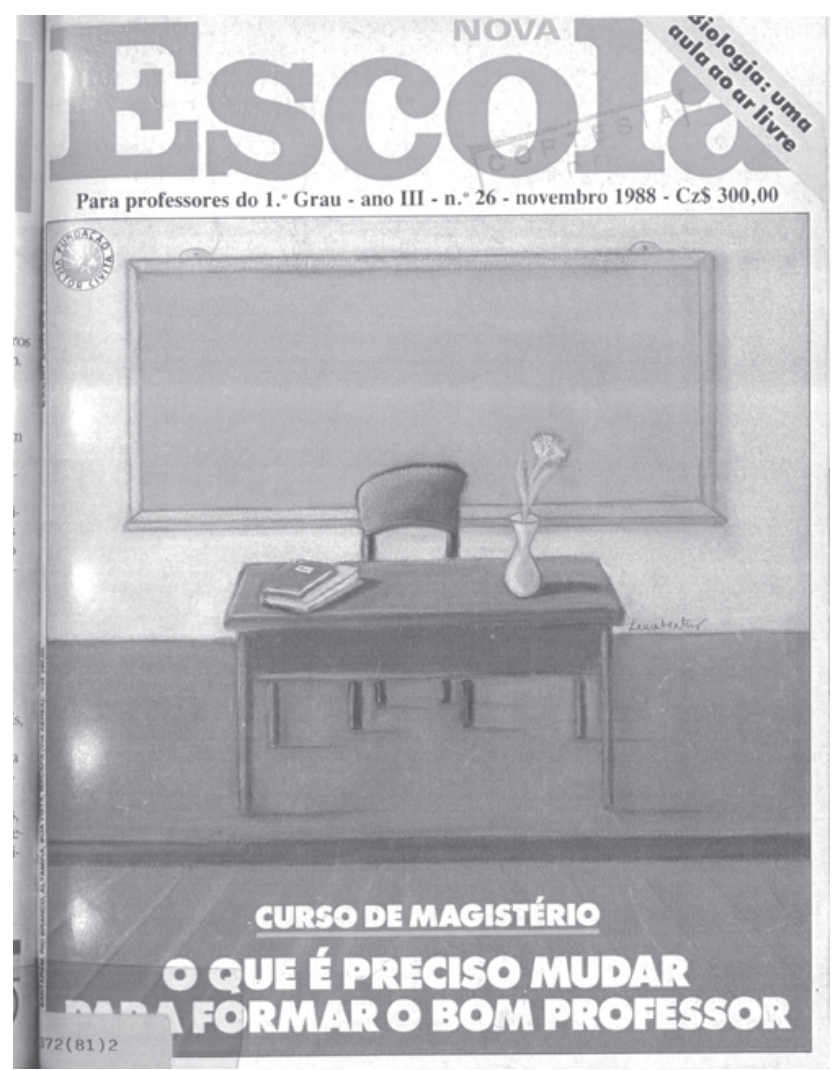

FIGURA 2 - Escola, ano III, n. 26, Nov. 1988 Fonte: Editora Abril.

O que emerge nessa capa surge sob a forma do que é desconhecido, do que não apresenta contornos definidos, do que é mesmo um lugar vazio e que, ao mesmo tempo, é conclamado nos discursos educacionais do período: o "bom professor" \% um significante para um lugar vazio. O que sobressai na imagem é a sua ausência, numa sala de aula onde tudo parece disposto para que ele apareça. Há uma lousa, uma escrivaninha sobre o velho estrado, onde o professor fica num nível acima dos alunos, uma cadeira, alguns livros ou cadernos e um vaso com uma flor. Tudo como antigamente, poder-se-ia pensar. Por isso, a imagem talvez sugira uma outra coisa, que é o que a manchete enuncia: "O que é preciso mudar" para que "o bom professor" apareça, pois, com esses elementos, com essa escola tradicional, com a formação que o professor recebe para nela atuar, jamais será possível que esse professor tão aguardado apareça. É necessário um novo professor para uma Nova Escola $\%$ a escola cujos contornos estão sendo definidos pela própria revista, num período no qual nenhum discurso educacional mostra-se hegemônico. A reformulação dos cursos de formação de professores, dos cursos de Magistério, é um passo fundamental nessa direção, conforme sugere a reportagem relativa ao destaque de capa. ${ }^{9}$

\section{Da professora construtivista à professora-mercadoria}

Já no ano seguinte, em 1989, os contornos do "bom professor" começam a ficar mais nítidos. Esse também é o ano em que o nome e a foto de Emilia Ferreiro surgem na capa da Nova Escola, sendo essa pesquisadora a primeira figura pública ou "autoridade" relacionada com a educação que tem o privilégio de aparecer na capa desde o início dessa publicação. Nessa edição, de março de 1989, a revista atribui a mudança de postura dos professores às "idéias" de Emilia Ferreiro, na própria manchete de capa: "Revolução na alfabetização. Idéias de Emilia Ferreiro mudam a postura do professor". Além disso, na reportagem que corresponde ao destaque de capa, começa a ser utilizado o significante-mestre construtivismo, até então ausente nesse periódico. Em duas matérias desse mesmo ano, nas quais o nome Emilia Ferreiro comparece, o que adquire maior relevância é precisamente o "bom professor", o professor eficiente ou eficaz, primeiramente relacionado com a alfabetização. ${ }^{10}$

Mas apenas em 1993, quando o construtivismo já é um discurso hegemônico, o que havia sido antecipado e instituído como um lugar vazio em $1988 \%$ e que o significante "bom professor" fazia circular $\%$ adquire contornos bem definidos, com a imagem nítida e concreta de uma professora construtivista: a professora Bernadete (Figura 3) Com ela, o lugar do "bom professor" é finalmente preenchido. $\mathrm{Na}$ imagem, ela aparece num primeiro plano, "com ar de vitoriosa, de quem obteve sucesso", como nota Vieira (1995, p. 49). Num segundo plano, a sala de aula, com

\footnotetext{
9 Sasaki, "Uma fábrica sem controle de qualidade”, Nova Escola (26), 12-22, nov. 1988.

${ }^{10}$ Souza, "O que o professor eficiente tem de especial", Nova Escola, (31), 28-9, jun. 1989, Guerra, "Sem afeto, não há alfabetização”, Nova Escola, (32), 22-4, ago. 1989.
} 
seus alunos, que estão como que a aclamando. Não estamos mais no registro de 1986. Agora, o destaque é para o professor na sua sala de aula.

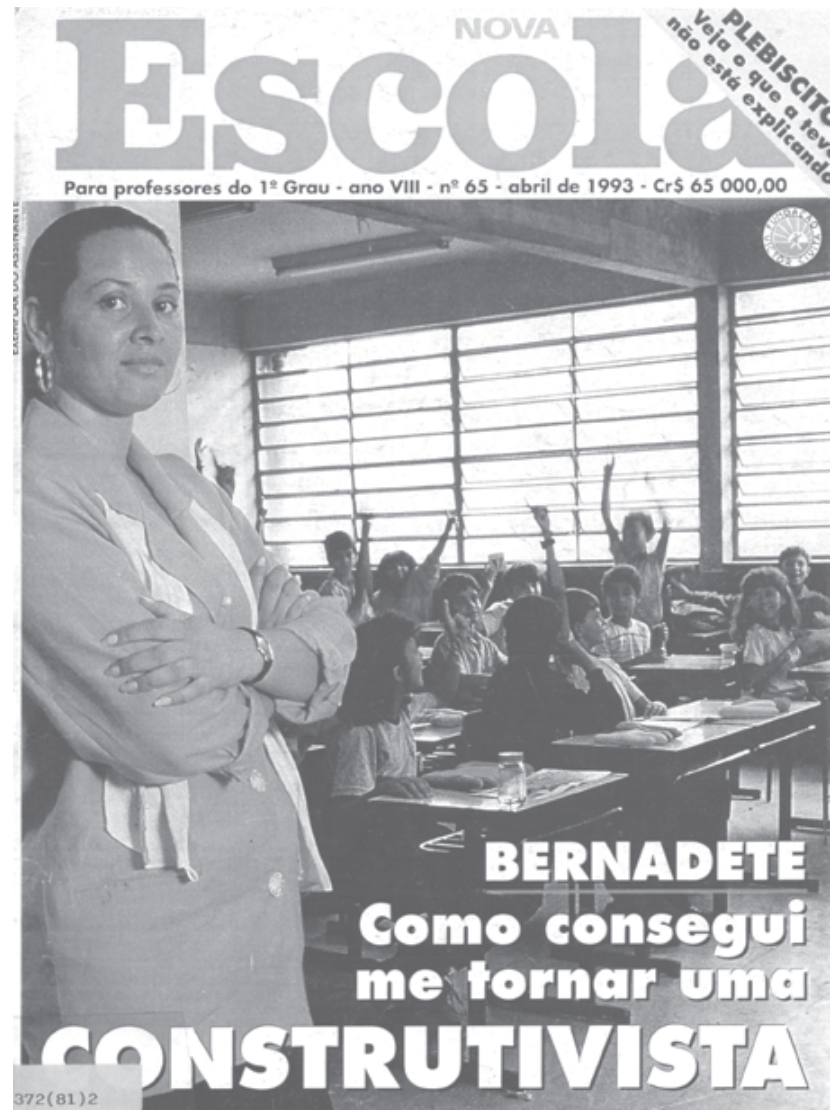

FIGURA 3 - Nova Escola, ano VIII, n. 65, abr. 1993 Fonte: Editora Abril.

Nessa edição, Bernadete torna-se "a" principal figura da Nova Escola, ela é o objeto que preenche o vazio que a própria revista evidenciou, mas que também configurou, e que circulava ordenando boa parte dos discursos pedagógicos. $\mathrm{Na}$ rota desse vazio parece ter penetrado a palavra construtivismo, assim definindo um circuito onde todos os professores foram incluídos, com essa palavra sendo transformada no significante-mestre que daí em mais fixará as suas posições. Um circuito, portanto, que aqui é entendido em sua dimensão significante, como circuito do desejo, no qual configurou-se um lugar vazio imaginariamente preenchido, pois desse circuito onde circulava " $a$ " falta, emergiu o que faltava: "a" figura da professora construtivista. ${ }^{11}$ Esta, doravante, parece ter de suportar o que é próprio do objeto que promete a plena satisfação do desejo e que Lacan conceitualizou chamando-o de objeto " a", o objeto causa do desejo, um objeto na verdade impossível de ser apreendido. No caso da professora, ocupar um lugar que corresponde ao que é da ordem desse objeto significa suportar tudo o que se encontra implicado na promessa de resolver o que, desde a década de 1970, vez por outra ficava no centro dos debates educacionais sobre a escola pública, o chamado fracasso escolar, relacionado sobretudo com a alfabetização e as altas taxas de reprovação nas primeiras séries do $1^{\circ}$ Grau. Sem contar a sua responsabilidade pelo que nesse período tornou-se o único eixo da maioria dos discursos oficiais e dos debates acadêmicos sobre a educação escolar pública: a qualidade do ensino.

Segundo a reportagem, para tornar-se uma construtivista, Bernadete precisou percorrer um "longo" e "pedregoso" caminho, um "caminho sem volta", no qual adquiriu novos hábitos e mudou até de aparência, passando por uma "radical mudança de postura". ${ }^{12}$ Tantas "agruras", porém, foram compensadas pela "felicidade de estar caminhando junto com seus alunos". Bernadete é o protótipo de professora construtivista que se mantém afastada do que nesse discurso define os seus extremos: o "professor tradicional" e o "professor espontaneísta" - na reportagem implicados quando delineada a atuação de outras duas professoras e nas críticas feitas a outros professores. Ambos encontram-se unidos no mesmo ponto de ressonância, o ponto dos "desvios, confusões, equívocos...", que define uma espécie de origem do construtivismo; "origem" que professoras como Bernadete conseguiram deixar para trás, para caminhar em direção ao que no discurso construtivista afigura o lugar do ideal. $\mathrm{Na}$ década de 1990, sobretudo no período que corresponde ao que predomina nessa reportagem, o professor tende a oscilar entre essas duas posições: entre afigurar a falta, entendida como lugar dos "desvios, confusões, equívocos...", e "o que" falta, enquanto objeto que acena com o ideal de completude. Nesse intervalo, entre essas posições, foi criado o que na revista Nova Escola afigura um caminho: o "caminho construtivista", que é o que daí em mais define o circuito do desejo de inúmeros professores. Esse circuito nasce com e sob essa ambivalência e em grande parte a mantém, porque dela própria se nutre. Essa

\footnotetext{
${ }^{11}$ Acima, alude-se ao que Lacan chama de imaginário.

${ }^{12}$ Lagôa, "As agruras do caminho construtivista", Nova Escola, (65), 8-14, 1993.
} 
ambivalência, essa oscilação, entre os "erros" e o ideal, entre não ser nada e ser o que todos consideram essencial ("O bom professor") não concerne apenas ao registro que é próprio dos discursos brasileiros. António Nóvoa (1999, p. 13-4), por exemplo, refere-se à mesma questão:

Por um lado, os professores são olhados com desconfiança, acusados de serem profissionais medíocres e de terem uma formação deficiente; por outro lado, são bombardeados com uma retórica cada vez mais abundante que os considera elementos essenciais para a melhoria da qualidade do ensino e para o progresso social e cultural.

No Brasil, essa ambivalência tornou-se particularmente intensa, talvez tão intensa quanto o "abalo sísmico" que o construtivismo parece ter provocado, como afirmam alguns autores (Corazza, 1994, p. 123). É uma ambivalência nutrida por abismos históricos, por demandas que com o construtivismo recaem sobre o professor. Deste, exige-se que na sala de aula desate os grandes e históricos nós da educação pública, como é o caso do analfabetismo, que é o que se promete resolver com a chamada "nova proposta" de alfabetização.

Para evidenciar a magnitude desse contraste, dessa ambivalência que a posição do professor deve suportar, podemos colocar lado a lado duas capas da Nova Escola, duas capas que evidenciam esse contraste e que ao mesmo tempo confluem para configurar essa particular posição (Figuras 4 e 5). A primeira é de março/90 e põe em destaque o "Analfabetismo. A vergonha nacional". A outra é de maio/92 e apresenta a imagem da conhecida "educadora gaúcha Esther Pillar Grossi", que "não tem a menor dúvida: o construtivismo pode, em pouco tempo, mudar o Brasil". ${ }^{13}$ Afinal, "Em matéria de alfabetização damos banho no Primeiro Mundo", conforme destaca a manchete dessa edição. O "caminho construtivista" é estendido entre esses dois pontos: entre a "vergonha" de um território sem as "primeiras letras" (Figura 4) e um lugar que "em matéria de alfabetização" supera o que o Primeiro Mundo oferece, como se estivéssemos "além" dele (Figura 5). "As agruras do caminho construtivista" muito devem ao que se aninha nessas duas bordas, muito devem a "isso" que é criado sob a forma da "origem" e dos ideais.

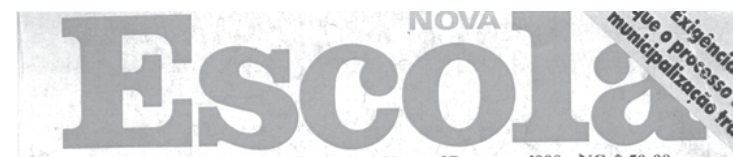

Para professores do 1. Grau - ano V - n. 37 - março 1990 - NCz\$ 50,00

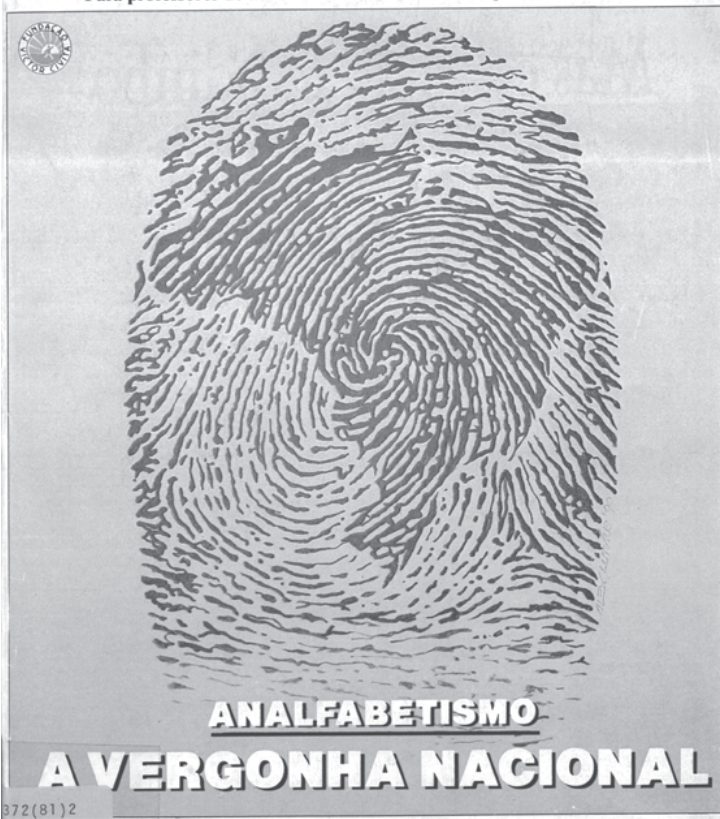

FIGURA 4 - Nova Escola, ano V, n. 37, mar. 1990 Fonte: Editora Abril.

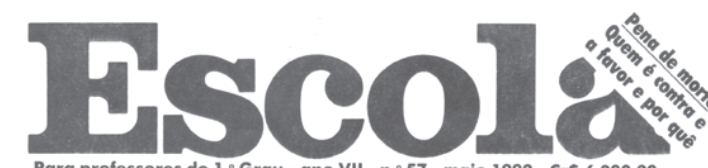

1992 - Crs 6000,00

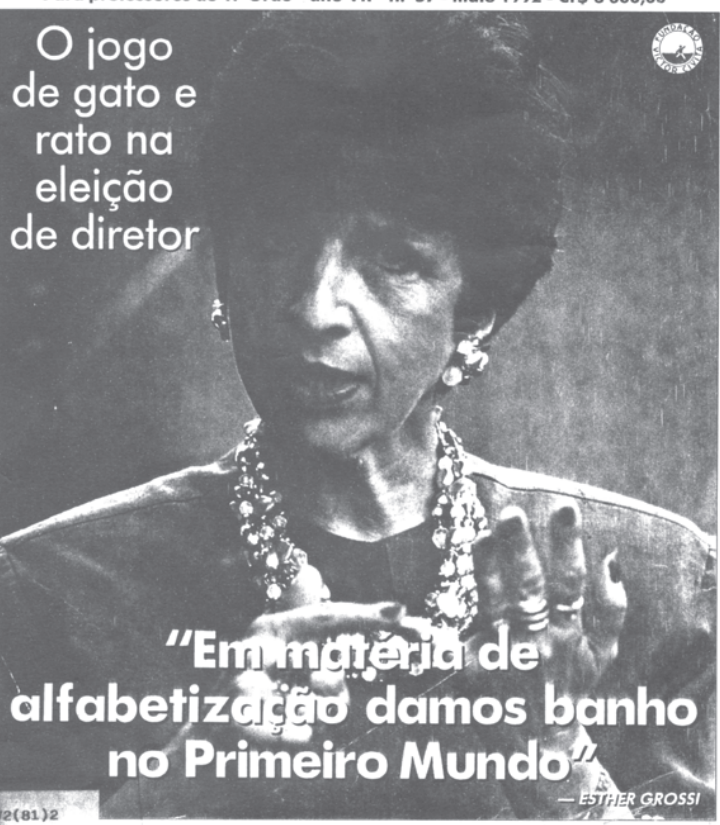

FIGURA 5 - Ano VII, n. 57, maio, 1992

Fonte: Editora Abril.

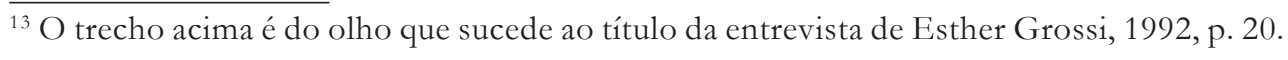


As "agruras" para se tornar uma "boa professora" tendem a desaparecer quando o discurso pedagógico começa a gravitar em torno de significantes que esvaziam a figura do professor. Nesse momento, que na revista Nova Escola alcança o seu ápice no ano de 1996, a ação pedagógica bem-sucedida resulta sobretudo das qualidades atribuídas a determinados objetos didáticos que circulam nas páginas da revista, como objetos de consumo, para leitores vistos primeiramente como consumidores. Até mesmo as professoras e as crianças-alunos tendem a ser transformados em meros objetos de consumo, em mercadorias oferecidas aos leitores. Um bom exemplo disso são as imagens de capa de 1996. Nelas, todas as crianças-alunos são anônimas e na maioria das capas não se sabe a quais escolas pertencem - um fato que contrasta com o que se observa, por exemplo, nas capas do primeiro ano da Nova Escola (Revah, 2007b). A única exceção

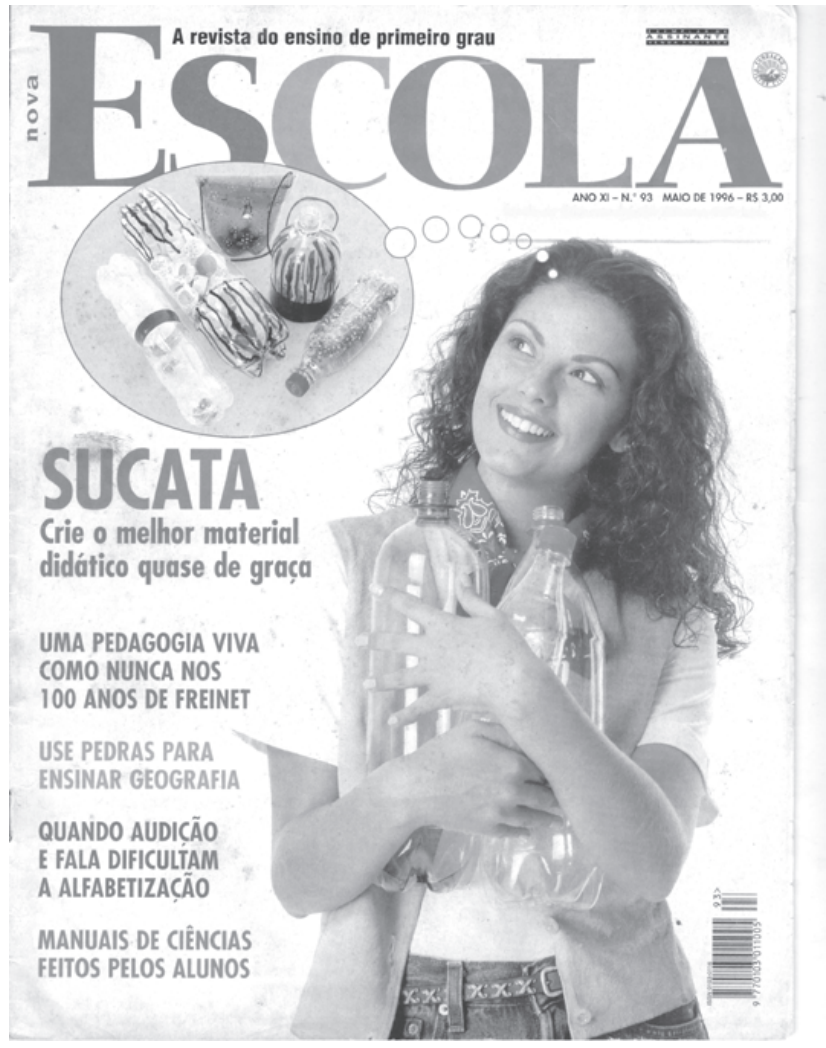

FIGURA 6 - Nova Escola, ano XI, n. 93, maio, 1996 Fonte: Editora Abril. é a capa de setembro/96, com crianças-alunos de uma escola privada mencionada na reportagem correspondente. Aliás, nesse período, contrastando com o que predomina na década de 1980 e parte da seguinte, as escolas privadas constituem referências importantes, senão únicas, em muitas matérias. Quanto às supostas professoras das capas desse ano (uma em maio, outra em junho), tampouco é possível saber o nome nem a qual escola pertencem, pois, ao que tudo indica, trata-se de modelos contratadas para as fotos dessas capas. Elas e as crianças-anônimas exibem determinadas roupas e objetos de grife. Essas, aliás, são as únicas informações presentes nos créditos de capa. Um exemplo é o da professora-modelo "produzida" para a capa de maio: "foto de J. Butsuen com produção de Wylma e Maríla Campos Mello. Camisa e calça: Levi's Wonderfit; colete: Mixer; tênis: M2000; Hair \& Make-up: Eric Wolfe."

$\mathrm{Na}$ Figura 6 a professora-mercadoria está abraçando várias garrafas vazias, com um sorriso estampado em seu rosto e o olhar dirigido ao que afigura os seus pensamentos, as suas ideias, os seus desejos: as mesmas garrafas transformadas em materiais didáticos. A manchete que acompanha a imagem é "Sucata", com este enunciado complementar: "Crie o melhor material didático quase de graça”. O destaque na capa dessa edição é o que predomina nesse período, no qual os responsáveis pelo sucesso da ação pedagógica não são propriamente as professoras, mas antes determinados objetos didáticos. São eles os que garantem o sucesso da ação da professora: um bom material didático, um conteúdo que "funciona", uma boa estratégia de ensino. Esses objetos didáticos são oferecidos nas páginas da Nova Escola, que também destaca o papel dos especialistas no saber didático que nesse momento parece cobiçado por todos os que comparecem nas páginas da revista. Um saber que é apresentado de forma concisa e clara, em textos que apresentam os passos e orientações prescritos pelos especialistas. Estes, nesse "ano didático", adquirem uma relevância nunca antes alcançada, se considerarmos a própria revista (é só observar 
o espaço a eles destinado nas próprias imagens de capa). Nesse ano, ademais, pela primeira vez nesse periódico, a capa da uma edição tem como grande destaque a figura de Piaget (1996).

Nesse período, não se fala mais em "agruras" do "caminho construtivista". Esse caminho parece ter se transformado numa veloz estrada moderna. À professora, basta seguir as instruções dos especialistas para ter sucesso em suas ações. Objeto desse saber, reduzida a executora de um saber que os especialistas possuem, a professora torna-se uma figura secundária, esvaziase, adquire o estofo do que pode ser substituído com facilidade, torna-se, ela própria, semelhante aos objetos que ocuparam o seu lugar, mas sem o seu brilho. Para brilhar, para ser uma "boa professora", precisa de toda a parafernália didática do mercado didático criado, entre outros, pela Nova Escola e pelos especialistas que nela comparecem. Além disso, graças a eles, parece ficar reduzida ao que é da ordem do objeto-mercadoria.

\section{REFERÊNCIAS}

Civita, V. (1986). Carta do editor. Nova Escola, I(1), 5.

Corazza, S. M. (1994). "Construtivismo: Que lugar é este?” Educação \& Realidade, 19(1), 121-24.

Ferraz, C. R. (1988). Pais x professores: O papel de cada um na alfabetização. Nova Escola, III(22), 12-17.

Ferreiro, E., Teberosky, A. (1986). Psicogênese da língua escrita. Porto Alegre: Artes Médicas.

Grossi, E. (1992). Em matéria de alfabetização damos banho no Primeiro Mundo. Nova Escola, VII(57), 20-23.

Guerra, R. (1989). "Sem afeto, não há alfabetização". Nova Escola, IV(32), 22-24.

Lacan, J. (1997). "O ponto de basta". In Lacan, J. O seminário, livro 3: As psicoses. (pp. 292-305). Rio de Janeiro: Zahar.

Lagôa, A. (1993). As agruras do caminho construtivista. Nova Escola, VIII(65), 8-14.

Nascimento, A. (1986). Reforma silenciosa. Nova Escola, I(2), 10-17.
Nóvoa, A. (1999). Os professores na virada do milênio: do excesso dos discursos à pobreza das práticas. Educação e Pesquisa, 25(1), 11-20.

Patto, M. H. S. (1985). A criança da escola pública: deficiente, diferente ou mal trabalhada? In E. S. Sá Barreto, M. C. G. Duran (Org.). Revendo a proposta de alfabetização. (pp. 13-21). São Paulo: SE/CENP.

Revah, D. (2004). Construtivismo: Uma palavra no circuito do desejo. Tese de Doutorado, Faculdade de Educação, Universidade de São Paulo, São Paulo.

Revah, D. (2007a). Configuração do impresso sob a ordem construtivista. In: Anais do $16^{\circ} \mathrm{COLE}$ Recuperado em 21 nov. 2008, em http:// www.alb.com.br/anais $16 /$ s em 07 pdf/ sm07ss15_01.pdf

Revah, D. (2007b) Imagens no "caminho construtivista" da nova escola. In G de SOUZA (Org.). A criança em perspectiva: Olhares do mundo sobre o tempo infância. (pp. 114-150). São Paulo: Cortez.

Sader, E. (1988). Quando novos personagens entraram em cena: Experiências, falas e lutas dos trabalhadores da Grande São Paulo, 19701980. Rio de Janeiro: Paz e Terra.

Sasaki, R. (1988). Uma fábrica sem controle de qualidade. Nova Escola, III(26), 12-22.

Saviani, D. (1984). Escola e democracia. São Paulo: Cortez.

Souza, N. de (1989). O que o professor eficiente tem de especial. Nova Escola, IV(31), 28-29.

Vieira, M. L. (1995). Construtivismo: A prática de uma metáfora. Forma/conteúdo do "construtivismo" em NOVA ESCOLA. Dissertação de Mestrado, Universidade Federal de Minas Gerais, Minas Gerais.

Recebido: 20/02/2009

Received: 02/20/2009

Aprovado: 24/04/2009

Approved: 04/24/2009

Revisado: 11/12/2009

Reviewed: 12/11/2009 